\title{
PENGARUH KUALITAS PELAYANAN JASA TERHADAP KEPUASAN PENGGUNA KOLAM RENANG UNIVERSITAS NEGERI YOGYAKARTA KAMPUS WATES
}

\author{
Martono \\ Fakultas Ilmu Keolahragaan, Universitas Negeri Yogyakarta, Jl. Colombo No. 1, Karangmalang Depok, Sleman, \\ Yogyakarta, Indonesia \\ martonofik@uny.ac.id
}

\begin{abstract}
Abstrak
Kolam renang Universitas Negeri Yogyakarta kampus Wates merupakan sarana tempat yang disewakan untuk umum. Penelitian ini bertujuan untuk mengetahui hubungan kualitas pelayanan terhadap kepuasan pengguna kolam renang Universitas Negeri Yogyakarta Wates. Permasalahan dalam penelitian ini adalah apakah kualitas pelayanan berpengaruh terhadap kepuasan pengguna di kolam renang Universitas Negeri Yogyakarta kampus Wates. Variabel dalam penelitian ini adalah Kualitas Pelayanan (X) dan Kepuasan pelanggan (Y). Penelitian ini merupakan penelitian deskriptif kuantitatif. Subjek penelitian ini adalah pengguna kolam renang UNY Wates yang terletak di Jalan Mandung Pengasih Kabupaten Kulon Progo Daerah Istimewa Yogyakarta 55651. Penelitian ini menggunakan sampel berukuran 100 responden. Pengambilan sampel menggunakan metode Accidental Sampling. Metode yang digunakan dalam pengumpulan data adalah survai dengan menggunakan instrumen angket. Objek penelitian ini berupa kualitas pelayanan dan kepuasan pengguna kolam renang Universitas Negeri Yogyakarta kampus Wates yang meliputi tangible, responsiveness, assurance, dan emphaty. Teknik analisis data deskriptif kuantitatif yang digunakan adalah dengan mengonversikan menjadi kategori sangat memuaskan, memuaskan, tidak memuaskan, dan sangat tidak memuaskan. Hasil penelitian menunjukkan bahwa kepuasan yang diterima oleh pengguna kolam renang Universitas Negeri Yogyakarta kampus Wates adalah memuaskan. Hasil penelitian menunjukkan bahwa kepuasan yang diterima oleh pengguna kolam renang Universitas Negeri Yogyakarta kampus Wates adalah memuaskan dengan presentase sebesar $69 \%$.
\end{abstract}

Kata Kunci: kualitas pelayanan, kepuasan pengguna, kolam renang

\section{THE INFLUENCE OF SERVICE QUALITY ON THE CUSTOMERS' SATISFACTION AT THE SWIMING POOL OF YOGYAKARTA STATE UNIVERSITY WATES.}

\begin{abstract}
Swiming pool of Yogyakarta State UniversityWates is a sport facility that is for rent to the public. This research aims to determine the influene of service quality on the customers' satisfaction at swiming pool of Yogyakarta State University Wates. The problems in this research were whether service quality have the impact to the customers' satisfaction at swiming pool of Yogyakarta State University. The research variables were Service Quality $(X))$ and Customers' Satisfaction $(Y)$. This research was descriptive quantitative. The subjects at this study were customers of swiming pool of Yogyakarta State University Wates at Mandung Street, Pengasih, Kulon Progo, Daerah Istimewa Yogyakarta 55651. This study consisted of 100 respondents. The sampling used in this research was by using accidental sampling method. The data collection technique used were survey using questionnaires. The objects of this research were service quality on the customers' satisfaction at the swiming pool of Yogyakarta State University Wates which includes tangible, reliability, responsiveness, assurance, and empathy. The data analysis technique used was by converting into highly satisfactory, satisfactory, unsatisfactory, and very unsatisfactory categories. The results show that users' satisfaction of swiming pool of
\end{abstract}


Yogyakarta State University Wates is satisfactory. The customers' satisfaction at swiming pool of Yogyakarta State University Wates was satisfying with a percentage of 69\%.

Keywords: service quality, user satisfaction, swimming pool

\section{PENDAHULUAN}

Memiliki tubuh yang bugar sangat diharapkan oleh semua orang. Dengan memiliki tubuh yang bugar seseorang akan terjaga kesehatannya dan bersemangat dalam melaksanakan aktivitas sehari-hari. Seiring gencarnya promosi pemerintah Indonesia mengkampanyekan kesadaran olahraga dalam bentuk kampanye Gerakan Masyarakat Untuk Hidup Sehat dan Sejahtera (GERMAS) yang tertuang dalam Instruksi Presiden Republik Indonesia Nomor 1 Tahun 2017 tentang Gerakan Masyarakat Hidup Sehat. Hal itu dapat dilihat dari meningkatnya aktivitas olahraga masyarakat setiap hari. Dengan semakin meningkatnya kesadaran masyarakat dalam berolahraga, tuntutan untuk sarana dan prasana olahragapun kebutuhannya semakin meningkat. Di beberapa daerah saat ini telah banyak pengusaha yang memiliki modal besar telah melakukan bisnis fasilitas olahraga seperti: penyewaan lapangan futsal, gelanggang olahraga, lapangan tenis, dan kolam renang. Kenyataannya beberapa pelaku usaha kecil menengah ataupun gabungan juga telah melirik peluang usaha kolam renang. Fasilitas kolam renang milik negara juga dikelola secara bisnis untuk membiayai perawatan kolam renang.

Kolam renang Universitas Negeri Yogyakarta kampus Wates (UNY Wates) yang terletak di Jalan Mandung, Pengasih, Kabupaten Kulon Progo, Daerah Istimewa Yogyakarta 55651 merupakan salah satu kolam renang yang ada di Daerah Istimewa Yogyakarta dan disewakan untuk umum. Konsumen dalam menggunakan jasa kolam renang tentu banyak memperhitungkan berbagai faktor baik tentang jarak maupun kualitas pelayanan yang disediakan oleh manajemen kolam renang. Oleh karena itu perkembangan dan peningkatan pelayanan jasa kolam renang dari tahun ke tahun semakin menjadi perhatian masyarakat. Hal ini dapat dilihat dari ketatnya persaingan kualitas pelayanan, harga, promosi di antara sekian banyaknya kolam renang.

Kolam renang UNY Wates merupakan sarana yang digunakan untuk peningkatan kebugaran, tempat rekreasi, tempat berlatih renang, bertanding, dan sarana refreshing. Kolam renang UNY Wates juga sering digunakan untuk pelatihan renang bagi atlet renang usia dini maupun atlet club-club renang yang berada di provinsi Daerah Istimewa Yogyakarta. Seiring dengan perkembangan zaman semakin hari jumlah pengguna yang bergabung menjadi pemakai kolam renang UNY Wates semakin bertambah. Suatu bisnis kolam renang ditentukan oleh kemampuan pengelola kolam renang itu sendiri dalam memberikan pelayanan yang memuaskan kepada para pelanggannya. Kepuasan pelanggan bisa menjadi senjata andalan untuk tampil sebagai pemenang dalam persaingan dalam dunia bisnis kolam renang yang semakin kompleks. Selain menawarkan berbagai macam layanan dan fasilitas sarana dan prasarana yang ada di kolam renang, manajemen juga biasanya menawarkan produk lain seperti tempat kursus renang maupun menyediakan souvenir maupun pakaian renang, upaya perbaikan di sisi teknologi informasi, pelayanan fisik, dan pelayanan nonfisik juga dimaksudkan untuk meningkatkan kualitas pelayanan (Ariyani, 2008).

Kualitas pelayanan merupakan salah satu faktor penentu keberhasilan yang memengaruhi daya saing bisnis. Sebuah perusahaan penyedia jasa kolam renang dapat membedakan dirinya dari pesaing dengan menyediakan layanan yang berkualitas tinggi. Kumar, et al. (2010: 211-228) menemukan bahwa kualitas pelayanan berpengaruh terhadap kepuasan pelanggan. Karyawan yang dengan segera bisa menyelesaikan masalah dapat meningkatkan kepuasan pelanggan. Melalui kepuasan, perusahaan penyedia jasa kolam renang berusaha membentuk kepercayaan kepada konsumennya. Lebih baik menjaga pelanggan yang sudah ada, sebelum memperoleh pelanggan baru (Walsh, et al. 2005: 421). 
Kualitas pelayanan merupakan salah satu unsur terpenting untuk menarik minat pembeli, kualitas pelayanan harus dirasakan oleh pelanggan secara utuh dan maksimal, usaha kualitas harus dimulai dengan kebutuhan pelanggan dan berakhir dengan persepsi pelanggan (Kotler, 1998: 90). Menurut Goetsh dan Davids yang dikutip oleh Tjiptono (2002: 51), kualitas merupakan suatu kondisi dinamis yang berhubungan dengan produk, jasa, manusia, proses dan lingkungan yang memenuhi atau melebihi harapan. Tjiptono (2002: 58) menyatakan bahwa secara garis besar ada empat unsur pokok dalam memberikan service excellence, yaitu kecepatan, ketepatan, keramahan, dan kenyamanan. Menurut Oliver yang dikutip oleh Supranto (2001: 233), kepuasan adalah tingkat perasaan seseorang setelah membandingkan kinerja atau hasil yang dirasakan dengan harapannya. Kepuasan adalah perasaan senang atau kecewa seseorang yang muncul setelah membandingkan antara persepsi atau kesannya terhadap kinerja atau hasil suatu produk dan harapan-harapannya (Kotler, 2002: 42). Menurut Engel, et al yang dikutip oleh Tjiptono (2002: 146), kepuasan pelanggan merupakan evaluasi purna beli di mana sekurang-kurangnya memberikan hasil (Outcome) sama atau melampaui harapan pelanggan".

Masyarakat semakin selektif dalam memilih sarana olahraga renang untuk menjaga kesehatan yang ada dalam dirinya dan kualitas kesehatan yang dimiliki guna menghindari risiko sakit akibat buruknya kualitas air dan prasarana pendukung yang ada pada kolam renang tersebut. Dalam hal ini, unsur kepercayaan menjadi faktor kunci bagi pelaku industri kolam renang untuk memenangkan hati pelanggan dan memenangkan kompetisi persaingan. Kepercayaan juga sangat diperlukan untuk membangun dan mempertahankan hubungan jangka panjang dengan konsumen atau pelanggan (Akbar dan Parves, 2009). Komitmen pelanggan yang tinggi terhadap industri kolam renang akan menjamin kelangsungan bisnis kolam renang jangka panjang.

Menurut Kotler (1994: 464):"'A service is any act performance that one party can offer to another that is essentially intangible and does not result in the ownership of anything. Its production may or may not be tied to physical product." Dengan kondisi persaingan yang semakin ketat di antara penyedia fasilitas kolam renang, hal utama yang harus diprioritaskan oleh penyedia jasa fasilitas kolam renang adalah memperhatikan kepuasan pelanggan atau pengguna dengan cara meberikan pelayanan terbaik dan memuaskan agar perusahaan atau penyedia jasa dapat bertahan, bersaing, dan menguasai pangsa pasar dan juga harus menyesuaikan harga dengan fasilitas yang diberikan.

Menurut Elhaitammy yang dikutip oleh Tjiptono (2002: 58), service excellence atau pelayanan yang unggul, yakni suatu sikap atau cara karyawan dalam melayani pelanggan secara memuaskan. Jadi kualitas pelayanan adalah kesesuaian harapan terhadap pelayanan suatu perusahaan dan apabila harapan konsumen dapat dipenuhi maka konsumen akan menjadi konsumen yang setia dan loyal terhadap bisnis kolam renang. Menurut Payne (2000: 8) jasa merupakan kegiatan yang memiliki beberapa unsur ketidakberwujudan (intangibility) yang berhubungan dengannya, yang melibatkan beberapa interaksi dengan konsumen atau dengan properti dalam kepemilikannya, dan tidak menghasilkan transfer kepemilikan. Perubahan kondisi mungkin saja terjadi dan produksi jasa bisa saja berhubungan atau bisa pula tidak berkaitan dengan produk fisik. Pelayanan jasa yang maksimal bisa mempengaruhi kepuasan pelanggan pada suatu bisnis fasilitas olahraga.

Penelitian Januar dan Ai (2016) tentang "Pengaruh Kualitas Pelayanan terhadap Kepuasan Pelanggan pada JNE Cabang Bandung" menunjukkan bahwa kualitas layanan (X) yang terdiri atas kehandalan, kepastian, kenyataan, empati, dan daya tanggap, memiliki pengaruh signifikan terhadap kepuasan pelanggan dengan nilai (nilai p) $0.003<0.05$. Sebagian hasil uji menunjukkan bahwa hanya variabel empati yang memiliki sebagian pengaruh dalam kepuasan pelanggan dengan jumlah variabel yang signifikan (nilai p) berjumlah $0.021<0.05$. 
Beberapa studi telah menghasilkan dimensi dalam penilaian kualitas pelayanan. Pada tahun 1988 Parasuraman dan kawan-kawan meramu dimensi kualitas jasa menjadi lima dimensi pokok Tjiptono (2002: 70), yaitu: (1) Bukti Langsung (Tangibles) Meliputi fasilitas fisik, perlengkapan, pegawai dan sarana komunikasi.(2) Keandalan (Reliability) Kemampuan memberikan pelayanan yang dijanjikan dengan segera, akurat dan memuaskan.(3) Daya Tanggap (Responsiveness) Keinginan para staf untuk membantu para pelanggan dan memberikan layanan dengan tanggap. (4) Jaminan (Assurance) Mencakup pengetahuan, kemampuan, kesopanan dan sifat dapat dipercaya yang dimiliki para staf; bebas dari bahaya, resiko atau keragu-raguan.(5) Empati (Emphaty) Meliputi kemudahan dalam melakukan hubungan, komunikasi yang baik, perhatian pribadi, dan memahami kebutuhan para pelanggan.

\section{METODE}

Penelitian ini adalah penelitian deskriptif kuantitatif dengan menggunakan metode survei, adapun teknik pengumpulan datanya dengan menggunakan angket. Penelitian ini dilaksanakan di kolam renang UNY Wates terletak di Jalan Mandung, Pengasih, Kabupaten Kulon Progo, Daerah Istimewa Yogyakarta 55651, dengan memberikan angket pada responden untuk mendapatkan data yang diperlukan. Populasi dalam penelitian ini adalah pelanggan yang berkunjung di kolam renang UNY Wates. Sampel diambil dengan metode accidental sampling. Sampel pada penelitian ini berjumlah 100 responden pengguna kolam renang UNY Wates. Dalam menganalisis data penelitian ini, peneliti menggunakan teknik analis deskriptif kuantitatif. Alternatif jawaban yang disediakan pada penelitian ini sejumlah empat pilihan (Arikunto, 1999: 246):

Tabel 1. Alternatif Jabawan pada Penelitian

\begin{tabular}{|l|c|}
\hline \multicolumn{1}{|c|}{ Kategori } & Nilai \\
\hline Sangat memuaskan & $76 \%-100 \%$ \\
\hline Memuaskan & $56 \%-75 \%$ \\
\hline Tidak memuaskan & $40 \%-55 \%$ \\
\hline Sangat tidak memuaskan & $<40 \%$ \\
\hline
\end{tabular}

Menurut Sugiono (1999: 89) rumus Likert merupakan metode pengukuran yang digunakan untuk mengukur sikap, pendapat, dan persepsi seseorang atau kelompok orang tentang fenomena sosial.

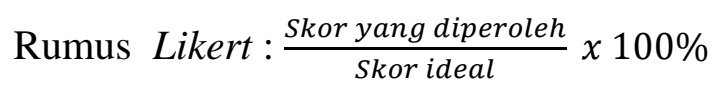

\section{HASIL DAN PEMBAHASAN}

\section{Variabel Kualitas Pelayanan}

Berdasarkan analisis data diperoleh distribusi frekuensi berdasarkan pengkategorian adalah sebagai berikut: 
Tabel 2.Distribusi Frekuensi Pengkategorian Kepuasan Pengguna terhadap Kualitas Pelayanan di Kolam Renang UNY Wates

\begin{tabular}{|c|l|c|c|c|}
\hline \multirow{2}{*}{ No. } & \multirow{2}{*}{ Kategori Jawaban } & \multirow{2}{*}{ Rentang Skor } & \multicolumn{2}{|c|}{ Frequency } \\
\cline { 4 - 5 } & & $76 \%-100 \%$ & Absolut & \% \\
\hline 1. & Sangat Memuaskan (SM) & $56 \%-75 \%$ & 69 & 31 \\
\hline 2. & Memuaskan (M) & $40 \%-55 \%$ & 0 & 0 \\
\hline 3. & Tidak Memuaskan (TM) & $<40 \%$ & 0 & 0 \\
\hline 4. & Sangat Tidak Memuaskan (STM) & 100 & 100 \\
\hline \multicolumn{2}{|c|}{ Total }
\end{tabular}

Tingkat kepuasan pengguna pada penelitian ini diukur dengan angket dan data yang diperoleh sebagian besar responden menyatakan puas dengan kualitas pelayanan jasa yang diberikan oleh kolam renang UNY Wates yaitu sebanyak 69 orang (69\%) menyatakan puas. Dengan demikian dapat disimpulkan bahwa kepuasa pengguna terhadap kualitas pelayanan jasa di kolam renang UNY Wates adalah memuaskan.

(1) Tangibles Data yang diperoleh sebagian besar responden menyatakan puas dengan kualitas pelayanan jasa yang diberikan oleh kolam renang UNY Wates yaitu sebanyak 77 orang (77\%) menyatakan puas. Dengan demikian dapat disimpulkan bahwa kepuasan pengguna terhadap tangibles di kolam renang UNY Wates adalah memuaskan.(2) Reliability Data yang diperoleh sebagian besar responden menyatakan puas dengan kualitas pelayanan jasa yang diberikan oleh kolam renang UNY Wates yaitu sebanyak 68 orang (68\%) menyatakan puas. Dengan demikian dapat disimpulkan bahwa kepuasan pengguna terhadap reliability di kolam renang UNY Wates adalah memuaskan.(3) Responsiveness data yang diperoleh sebagian besar responden menyatakan puas dengan kualitas pelayanan jasa yang diberikan oleh kolam renang UNY Wates yaitu sebanyak 75 orang $(75 \%)$ menyatakan puas. Dengan demikian dapat disimpulkan bahwa kepuasan pengguna terhadap responsiveness di kolam renang UNY Wates adalah memuaskan.(4) Assurance data yang diperoleh sebagian besar responden menyatakan puas dengan kualitas pelayanan jasa yang diberikan oleh kolam renang UNY Wates yaitu sebanyak 75 orang $(75 \%)$ menyatakan puas. Dengan demikian dapat disimpulkan bahwa kepuasan pengguna terhadap assurance di kolam renang UNY Wates adalah memuaskan.(5) Emphaty data yang diperoleh sebagian besar responden menyatakan puas dengan kualitas pelayanan jasa yang diberikan oleh kolam renang UNY Wates yaitu sebanyak 74 orang (74\%) menyatakan puas. Dengan demikian dapat disimpulkan bahwa kepuasan pengguna terhadap emphaty di kolam renang UNY Wates adalah memuaskan.

\section{Variabel Kepuasan Pengguna}

Berdasarkan analisis data diperoleh distribusi frekuensi berdasarkan pengkategorian adalah sebagai berikut:

Tabel 3. Distribusi Frekuensi Pengkategorian Kepuasan Pengguna Kolam Renang UNY Wates

\begin{tabular}{|c|l|c|c|c|}
\hline \multirow{2}{*}{ No. } & \multirow{2}{*}{ Kategori Jawaban } & \multirow{2}{*}{ Rentang Skor } & \multicolumn{2}{c|}{ Frequency } \\
\cline { 4 - 5 } & & & Absolut & \% \\
\hline 1. & Sangat Memuaskan (SM) & $76 \%-100 \%$ & 21 & 21 \\
\hline 2. & Memuaskan (M) & $56 \%-75 \%$ & 76 & 76 \\
\hline 3. & Tidak Memuaskan (TM) & $40 \%-55 \%$ & 3 & 3 \\
\hline 4. & Sangat Tidak Memuaskan (STM) & $<40 \%$ & 0 & 0 \\
\hline \multicolumn{2}{|c|}{ Total } & 100 & 100 \\
\hline
\end{tabular}

Data yang diperoleh sebagian besar responden menyatakan puas dengan jasa yang diberikan oleh kolam renang UNY Wates yaitu sebanyak 76 orang $(76 \%)$ menyatakan puas. Dengan demikian dapat disimpulkan bahwa kepuasa pengguna terhadap jasa di kolam renang UNY Wates adalah memuaskan. 


\section{SIMPULAN}

Berdasarkan hasil penelitian dan pembahasan dapat ditarik kesimpulan bahwa kepuasan yang diterima oleh pengguna kolam renang UNY Wates adalah memuaskan dengan presentase sebesar 69\%. Disarankan pengelola kolam renang UNY Wates dapat mempertahankan bahkan meningkatkan kualitas pelayanan lebih optimal. Pengelola kolam renang UNY Wates diharapkan tetap menjaga kebersihan ruang bilas, ruang ganti, kamar mandi, dan kejernihan air kolam renang. Pengelola kolam renang UNY Wates diharapkan menyediakan kotak saran dan kritik.

\section{DAFTAR PUSTAKA}

Akbar, M.M., \& Parvez, N. (2009). Impact of services quality, trust, and customer satisfaction on customer loyalty. ABAC Journal, 29(1), 24-38.

Arikunto, S. (1999). Prosedur penelitian suatu pendekatan praktek. Jakarta: PT. Rineka Cipta.

Ariyani, F. (2008). Membangun loyalitas nasabah melalui peningkatan kualitas pelayanan dan keunggulan produk (studi empiris pada pt. bank bukopin tbk di kota semarang), Tesis, Magister Manajemen Universitas Diponegoro, Semarang.

Kottler, P. (1994). Marketing management analysis and planning, implementation and control. $8^{\text {th }}$ ed. Prentice Hall Inc. USA.

Kottler, P. (1998). Manajemen pemasaran: analisis, perencanaan, implementasi, dan kontrol. Jilid Dua. (Hendra Teguh dan Ronny Antonius Rusli. Terjemahan). Jakarta: Prenhallindo. Buku asli diterbitkan tahun 1997.

Kotler, P., et al. (2002). Manajemen pemasaran. Jilid Satu. (Hendra Teguh, Ronny Antonius Rusli dan Benjamin Molan. Terjemahan). Jakarta: Prenhallindo. Buku asli diterbitkan tahun 2000.

Kumar, M., Kee, F. T., \& Manshor, A. T. (2010). Determining the relative importance of critical factors in delivering service quality of banks: an application of dominance analysis in servqual model, Managing Service Quality, 19(2), 211-228.

Panjaitan, Januar, E., \& A. L. Yuliati. (2016). Pengaruh kualitas pelayanan terhadap kepuasan pelanggan pada JNE cabang bandung. DeReMa Jurnal Manajemen, 11(2), 142-167.

Payne, A. (2000). Pemasaran jasa. (Fandy Tjiptono. Terjemahan). Yogyakarta: Andi Offset. Buku asli diterbitkan tahun 1993.

Sugiyono. (1999). Metode penelitian bisnis. Bandung: Alfabeta.

Tjiptono, F. (2002). Strategi pemasaran. Ed. 2. Cet. 5. Yogyakarta: Andi Offset.

Walsh, G., Groth, M., \& Wiedmann, K. P. (2005). An examination of consumers'motives to switch energy suppliers, Journal of Marketing Management, 21, 421-440.

Instruksi Presiden Republik Indonesia Nomor 1 Tahun 2017 Tentang Gerakan Masyarakat Hidup Sehat. 